\title{
Evidence for 'escape through spawning' in large gilthead sea bream Sparus aurata reared in commercial sea-cages
}

\author{
Stylianos Somarakis ${ }^{1, *}$, Michail Pavlidis ${ }^{2}$, Christina Saapoglou ${ }^{1,2}$, \\ Costas S. Tsigenopoulos ${ }^{1}$, Tim Dempster ${ }^{3,4}$ \\ ${ }^{1}$ Hellenic Centre for Marine Research (HCMR), PO Box 2214, 71003 Heraklion, Crete, Greece \\ ${ }^{2}$ Department of Biology, University of Crete, PO Box 2208, 71409, Heraklion, Crete, Greece \\ ${ }^{3}$ Centre for Research-based Innovation in Aquaculture Technology (CREATE), SINTEF Fisheries and Aquaculture, \\ 7465 Trondheim, Norway \\ ${ }^{4}$ Department of Zoology, University of Melbourne, Victoria 3010, Australia
}

\begin{abstract}
During the last decade, farming of species that may reproduce within marine fish farms has become more common. However, knowledge of the extent and ecological effects of reproduction of farmed fish within commercial farms is sparse. We examined whether large gilthead sea bream Sparus aurata reared in farms in Greece produced fertilized eggs that survived and dispersed into surrounding waters. Extensive histological investigation of gonads sampled from 5 different farms revealed that female sea bream cultivated beyond the size of sex reversal matured, ovulated and released eggs during the normal spawning period of the species. Annual fecundities (108 $000 \pm 60081$ eggs kg ${ }^{-1}$ of female in farms) were low relative to commercial broodstock and decreased considerably with sex ratio (i.e. with fish size in the cage). An egg-collector experiment and site-intensive ichthyoplankton study with genetic identification of sparid eggs demonstrated that sea bream eggs were spawned in farms and released to the environment. If $5-10 \%$ of the 130000 tons $\mathrm{yr}^{-1}$ production is fish of larger size, we estimate that $3.5 \times 10^{11}$ to $7.0 \times$ $10^{11}$ eggs $\mathrm{yr}^{-1}$ are released into the Mediterranean Sea. Whilst we documented low daily survival rates of fertilized eggs in the vicinity of sea-cages, our findings imply that the escape of eggs from sea bream farms may have ecological consequences, which likely depend on the sex ratio and intensity of farming within specific regions. To avoid potentially negative ecological and genetic consequences of escape through spawning, farms with large fish should not be placed close to the nursery grounds of wild sea bream, such as in coastal lagoons.
\end{abstract}

KEY WORDS: Aquaculture $\cdot$ Sparus aurata $\cdot$ Escape $\cdot$ Fecundity $\cdot$ Egg collector $\cdot$ Ichthyoplankton Resale or republication not permitted without written consent of the publisher

\section{INTRODUCTION}

The escape of fish from sea-cage aquaculture may lead to undesirable genetic effects in native populations through interbreeding, and ecological effects through predation, competition and the transfer of diseases to wild fish (Fleming et al. 2000, CIESM 2007, Thorstad et al. 2008, Jensen et al. 2010,
Arechavala-Lopez et al. 2012). In European waters, escape events of juvenile and adult fish occur mostly as a result of structural failures during storms and the appearance of holes in nets (Jensen et al. 2010, Jackson et al. 2012).

Recently, a second form of escape has come into focus, involving the escape of fertilized eggs spawned by farmed individuals from sea-cages (Jørstad et 
al. 2008). Maturation and spawning of Atlantic cod Gadus morhua is widespread throughout the industry and this species has the potential to produce large amounts of viable eggs and larvae (Uglem et al. 2012). Escaped cod eggs disperse into the environment (Jørstad et al. 2008, Uglem et al. 2012), survive to become young-of-the-year, recruit to spawning populations and successfully spawn in the wild (van der Meeren et al. 2012). The broader ecological consequences of this new form of escape are largely unknown.

In the Mediterranean Sea, information about spawning by fish kept in sea-cages is sparse. In Greece-the largest EU producer of gilthead sea bream Sparus aurata - both the number of fish farms and their production capacity increased over the past $15 \mathrm{yr}$. The main method for on-growing of gilthead sea bream is in floating sea-cages where fish are kept for a period of 12 to 18 mo until they reach the typical marketable size of 300-400 g (Petridis \& Rogdakis 1996, EFSA 2008). However, changes in consumers' habits (a growing proportion of the population is reluctant to buy whole fish), the need for product diversification (value-added fillets), and the higher prices that whole large-sized $(>800 \mathrm{~g})$ fish attain in the market prompted several producers to expand the on-growing period for up to 40 mo or more to harvest larger fish (Dimitriou et al. 2007, Barazi-Yeroulanos 2010). The increased farming duration has resulted in the production of sea bream of a size compatible with that necessary for sex reversal and female sexual maturation. Based mainly on indirect evidence, Dimitriou et al. (2007) suggested that following this change in the rearing process, there is, presently, a high possibility that both male and female gametes are produced within sea-cages and that fertilised eggs escape into surrounding coastal habitats.

The gilthead sea bream is a protandrous hermaphroditic fish with all individuals functioning as males during their first maturity (i.e. at the end of their first or second year of life), thereafter changing sex, with a certain fraction of fish functioning as females during the second spawning season (Zohar et al. 1978, Zohar et al. 1984, Pavlidis et al. 2006, Mylonas et al. 2011). The percentage of sex-reversed 2- or 3-yr-old fish undergoing their second gonadal maturation varies from 15 to $80 \%$ and it increases in subsequent reproductive periods (Arias 1980, Kadmon et al. 1985, Bruslé-Sicard \& Fourcault 1997).

As for most sparid species, sea bream is a multiple spawner with asynchronous oocyte development (Mylonas et al. 2011). Its spawning period extends from October to December in northern latitudes and from December to April in the southern Mediter- ranean, and females are characterized by high interspawning intervals and annual fecundities $(>2.0 \times$ $10^{6}$ eggs $\mathrm{kg}^{-1}$ ) (Barbaro et al. 1997, Zohar et al. 1995, EFSA 2008, Mylonas et al. 2011, M. Pavlidis unpubl. data). In commercial hatcheries where broodfish are kept, fertilization rates and hatching rates of naturally spawned eggs are typically high (Mylonas et al. 2011).

The objectives of this study were to: (1) investigate whether large fish, i.e. fish beyond the size of sex reversal and onset of female maturation, are likely to produce eggs within sea cages, using the Greek sea bream industry as a case study; (2) quantify egg production; and (c) assess whether the eggs potentially produced within sea-cages ultimately disperse and survive in surrounding coastal waters.

\section{MATERIALS AND METHODS}

\section{Spatial and temporal analysis of sea bream gonads in Greek farms}

Because of the complex reproductive biology of gilthead sea bream (sex reversal, indeterminate annual fecundity and extended spawning period), an intensive sampling survey was carried out in 5 farms in Greece (Table 1) to obtain and analyze gonads and provide estimates of daily and annual egg production. A total of 1262 large gilthead sea bream were sampled on a monthly basis from November 2009 to April 2010. Farms 1-3 were located in the Ionian Sea whereas Farms 4-5 were in the Aegean Sea (Fig. 1). Mean fish mass ranged from 0.82 to $1.75 \mathrm{~kg}$ and the percentage of females in samples ranged from 38 to $81 \%$ (Table 1).

Fish were measured (fork length; FL) to the nearest millimeter and weighed (total mass) to the nearest gram. Body cavities were opened, fish were sexed macroscopically and gonads were removed and weighed to the nearest milligram. A gonad sample $(50-100 \mathrm{~g})$ was taken from each fish from the middleto-posterior part of the organ and immediately preserved in $10 \%$ neutral buffered formalin for subsequent histological analysis. When possible, the gonad sample was also weighed (to the nearest gram) before fixation in formalin. When both ovarian and testicular tissues were macroscopically observed, we took care to include both tissues in the selected sub-sample.

In the laboratory, the preserved gonad samples were re-weighed and pieces of tissue were dehydrated and embedded in paraffin. Sections $(4-6 \mu \mathrm{m})$ were cut and stained with Mayer's hematoxylin and 
Table 1. Sparus aurata. Number of sea bream sampled (N), number of females, number of males, sex ratio (number of females/N), mean fork length (FL) and mean mass of sea bream per month per farm

\begin{tabular}{|c|c|c|c|c|c|c|c|c|}
\hline & Farm & Nov & Dec & Jan & Feb & Mar & Apr & Total \\
\hline $\mathrm{N}$ & $\begin{array}{l}1 \\
2 \\
3 \\
4 \\
5\end{array}$ & $\begin{array}{l}50 \\
50 \\
50 \\
21 \\
40\end{array}$ & $\begin{array}{l}50 \\
50 \\
50 \\
19 \\
40\end{array}$ & $\begin{array}{l}50 \\
50 \\
50 \\
20 \\
40\end{array}$ & $\begin{array}{l}50 \\
50 \\
50 \\
20 \\
40\end{array}$ & $\begin{array}{l}50 \\
50 \\
50 \\
20 \\
42\end{array}$ & $\begin{array}{l}50 \\
50 \\
50 \\
20 \\
40\end{array}$ & $\begin{array}{c}300 \\
300 \\
300 \\
120 \\
242 \\
1262\end{array}$ \\
\hline Females & $\begin{array}{l}1 \\
2 \\
3 \\
4 \\
5\end{array}$ & $\begin{array}{l}37 \\
29 \\
23 \\
15 \\
27\end{array}$ & $\begin{array}{c}39 \\
31 \\
19 \\
9 \\
29\end{array}$ & $\begin{array}{l}36 \\
28 \\
15 \\
16 \\
28\end{array}$ & $\begin{array}{l}44 \\
26 \\
17 \\
11 \\
28\end{array}$ & $\begin{array}{l}48 \\
39 \\
18 \\
12 \\
34\end{array}$ & $\begin{array}{l}39 \\
31 \\
23 \\
13 \\
29\end{array}$ & $\begin{array}{c}243 \\
184 \\
115 \\
76 \\
175 \\
793\end{array}$ \\
\hline Males & $\begin{array}{l}1 \\
2 \\
3 \\
4 \\
5\end{array}$ & $\begin{array}{c}13 \\
21 \\
27 \\
6 \\
13\end{array}$ & $\begin{array}{l}11 \\
19 \\
31 \\
10 \\
11\end{array}$ & $\begin{array}{c}14 \\
22 \\
35 \\
4 \\
12\end{array}$ & $\begin{array}{c}6 \\
24 \\
33 \\
9 \\
12\end{array}$ & $\begin{array}{c}2 \\
11 \\
32 \\
8 \\
8\end{array}$ & $\begin{array}{c}11 \\
19 \\
27 \\
7 \\
11\end{array}$ & $\begin{array}{c}57 \\
116 \\
185 \\
44 \\
67 \\
469\end{array}$ \\
\hline Sex ratio & $\begin{array}{l}\text { O } 1 \\
2 \\
3 \\
4 \\
5\end{array}$ & $\begin{array}{l}0.74 \\
0.58 \\
0.46 \\
0.71 \\
0.68\end{array}$ & $\begin{array}{l}0.78 \\
0.62 \\
0.38 \\
0.47 \\
0.73\end{array}$ & $\begin{array}{l}0.72 \\
0.56 \\
0.30 \\
0.80 \\
0.70\end{array}$ & $\begin{array}{l}0.88 \\
0.52 \\
0.34 \\
0.55 \\
0.70\end{array}$ & $\begin{array}{l}0.96 \\
0.78 \\
0.36 \\
0.60 \\
0.81\end{array}$ & $\begin{array}{l}0.78 \\
0.62 \\
0.46 \\
0.65 \\
0.73\end{array}$ & $\begin{array}{l}0.81 \\
0.61 \\
0.38 \\
0.63 \\
0.72 \\
0.63\end{array}$ \\
\hline $\begin{array}{l}\text { Mean } \\
\text { FL } \\
(\mathrm{cm})\end{array}$ & $\begin{array}{l}1 \\
2 \\
3 \\
4 \\
5\end{array}$ & $\begin{array}{l}39.3 \\
37.2 \\
33.9 \\
38.3 \\
43.7\end{array}$ & $\begin{array}{l}39.0 \\
40.0 \\
32.9 \\
38.2 \\
43.5\end{array}$ & $\begin{array}{l}38.7 \\
39.1 \\
33.4 \\
36.3 \\
44.0\end{array}$ & $\begin{array}{l}38.9 \\
38.7 \\
32.8 \\
40.7 \\
43.8\end{array}$ & $\begin{array}{l}36.0 \\
39.2 \\
32.5 \\
38.8 \\
43.4\end{array}$ & $\begin{array}{l}36.3 \\
39.3 \\
33.9 \\
38.6 \\
42.7\end{array}$ & $\begin{array}{l}38.0 \\
39.0 \\
33.3 \\
38.4 \\
43.5 \\
38.8\end{array}$ \\
\hline $\begin{array}{l}\text { Mean } \\
\text { mass } \\
(\mathrm{kg})\end{array}$ & $\begin{array}{l}1 \\
2 \\
3 \\
4 \\
5\end{array}$ & $\begin{array}{l}1.451 \\
1.330 \\
0.923 \\
1.497 \\
2.006\end{array}$ & $\begin{array}{l}1.364 \\
1.674 \\
0.851 \\
1.492 \\
1.851\end{array}$ & $\begin{array}{l}1.215 \\
1.511 \\
0.835 \\
1.468 \\
1.805\end{array}$ & $\begin{array}{l}1.190 \\
1.359 \\
0.724 \\
1.572 \\
1.727\end{array}$ & $\begin{array}{l}0.948 \\
1.390 \\
0.733 \\
1.227 \\
1.640\end{array}$ & $\begin{array}{l}0.991 \\
1.350 \\
0.820 \\
1.216 \\
1.522\end{array}$ & $\begin{array}{l}1.182 \\
1.435 \\
0.820 \\
1.410 \\
1.752 \\
1.336\end{array}$ \\
\hline
\end{tabular}

eosin Y (Clark 1981). Histological scoring of functional ovaries included the stage of development of the most advanced oocytes, the presence and histological characteristics of postovulatory follicles, as well as the incidence, prevalence and state of atresia (sensu Hunter \& Macewitz 1985). The percentage of yolked oocytes in the alpha stage of atresia was measured in at least 100 oocytes in random optical fields on the slides. Atresia prevalence measurements included at least 10 females with yolked oocytes and all females with incidence of hydrated oocytes for each farm/month combination, when available.

Batch fecundity was measured by counting the number of hydrated oocytes in pre-weighed subsamples from the ovary (Hunter et al. 1985). Variability in batch fecundity (absolute fecundity as well as relative fecundity, i.e. number of eggs per gram of fish) was subsequently analyzed using general linear models. Fixed factors included month of sampling and farm of origin, whereas ovary-free mass and prevalence of atresia were the covariates. Marginal means fixed at overall average fish size and/or rates of atresia and their 95\% confidence intervals were estimated and compared between months and farms after Bonferroni adjustment of significance levels.

\section{Egg collector experiment}

An egg collection system was designed, manufactured and installed in a sea bream cage of a private fish farm (Farm 5, Fig. 1) located off the coast of the
Fig. 1. Location of the 5 sea bream Sparus aurata farms in Greece in which sampling for gonad analysis took place

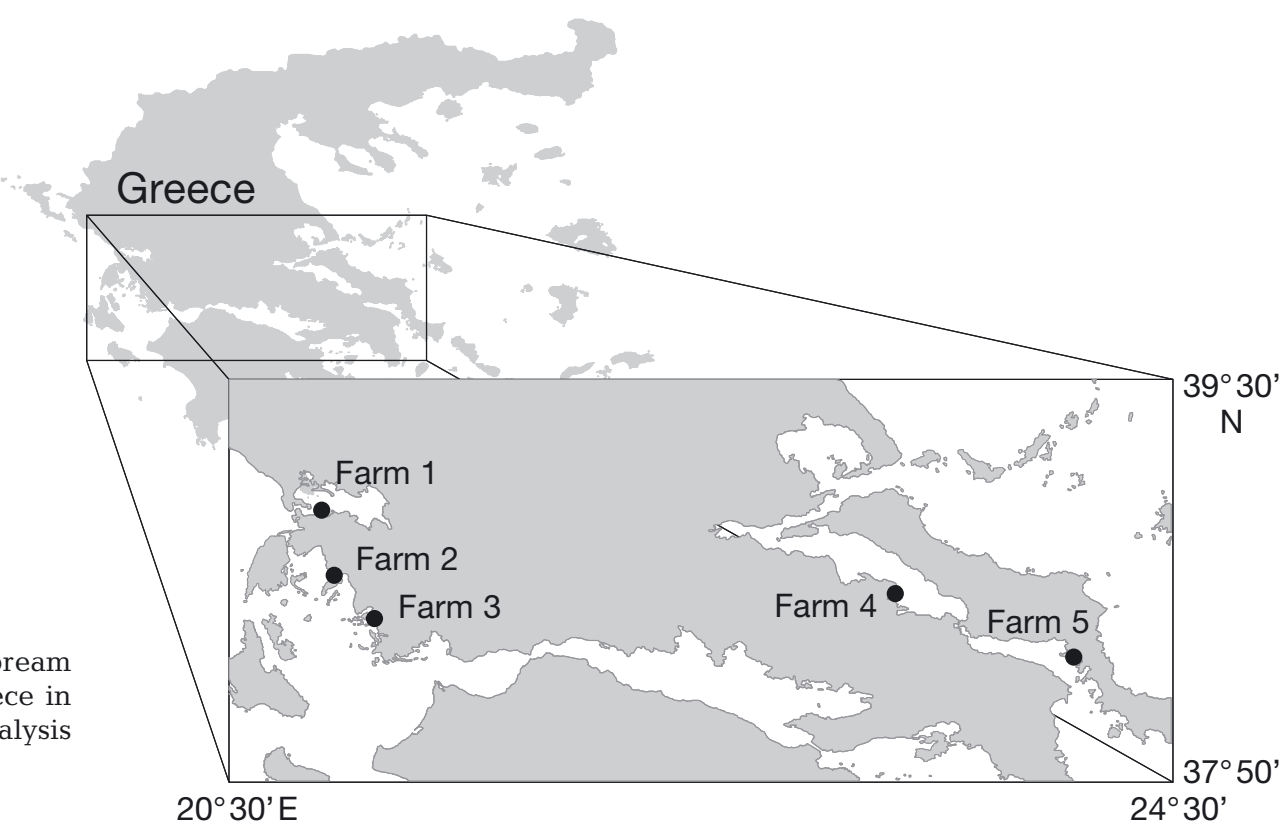


island of Evia, Greece. The egg collector (Fig. S1A,B in the supplement at www-int-res.com/articles/suppl/ q003p135_supp.pdf) consisted of a standard, heavyduty net (Monodur; height: $1 \mathrm{~m}$; mesh size: $0.120 \mathrm{~mm}$ ). A non-toxic polyethylene construction $(0.10 \times 0.30 \times$ $0.15 \mathrm{~m}$ ) was attached in the upper part of the collector to hang the whole system from the net pen collars. A lead line was knitted along the lower part of the net as well as in vertical belts (one every $2.75 \mathrm{~m}$ ) to hold the collector in the appropriate position within the net pen. To verify that eggs are released by gilthead sea bream held in sea-cages and further evaluate the numbers produced, a test experiment was performed in January-February 2011.

To ensure the best in situ conditions for spawning, the test experiment was performed with an ideal sex ratio (0.5), at a low stocking density, and with a number of fish similar to that used in commercial sea bream hatcheries. Sixty fish at a sex ratio of 0.5 (30 females and 30 males with a mean body mass of 990 and $577 \mathrm{~g}$, respectively) were placed in a net pen cage (diameter $40 \mathrm{~m}$, depth $10 \mathrm{~m}$ ) in the middle of January. A net of $40 \mathrm{~m}$ in perimeter and $4 \mathrm{~m}$ in height was placed within the sea cage to decrease the distance between spawning fish and the net collector (Fig. S1C,D in the supplement). Fish were left undisturbed for 2 wk before the egg collector/net complex was placed in the cage. Egg monitoring (Fig. S2 in the supplement) was performed on a daily basis for 2 consecutive weeks (11-25 February 2011).

Eggs were collected from 08:30 to 09:00 h, placed into a $10 \mathrm{l}$ plastic bucket, lightly agitated and transferred to land for counting and egg quality analyses.
Five $10 \mathrm{ml}$ samples were taken with a wide-mouthed pipette and placed in Petri dishes, and individual eggs were counted under a stereoscope. The mean was calculated and the total number of eggs in the bucket was estimated by extrapolation.

\section{Assessment of dispersal and mortality of eggs around sea bream sea-cages}

A site-intensive ichthyoplankton survey was carried out for 3 consecutive days from 20 to 22 January 2011 around fish Farm 5 (Fig. 1). There were several other farms in the surveyed area, but we focused on the selected farm as it was the only one that raised sea bream beyond the size of sex reversal. Sampling took place onboard the $26 \mathrm{~m} \mathrm{RV}$ 'Philia'. On each day, vertical hauls of a standard WP2 net $(0.2 \mathrm{~mm}$ mesh, mouth area of $0.25 \mathrm{~m}^{2}$ ) were performed at 19 fixed stations from $4 \mathrm{~m}$ above the sea bottom to the surface to collect fish eggs and larvae (Fig. 2). Sampling took place from 10:00 to 19:00 $\mathrm{h}$ on 20 January 2011 and from 9:00 to 16:00 h on 21 and 22 January 2011. Sampling was more intensive around the farm to capture the small-sized egg patch of newly spawned eggs that was expected if they were being produced inside the sea-cages. A SBE-25 CTD profiler was used to record the temperature and salinity of the water column. The ichthyoplankton samples were sorted onboard immediately after capture, and all fish eggs and larvae were identified to the lowest possible taxonomic level.

Gilthead sea bream eggs and early larvae are largely indistinguishable from other winter spawning

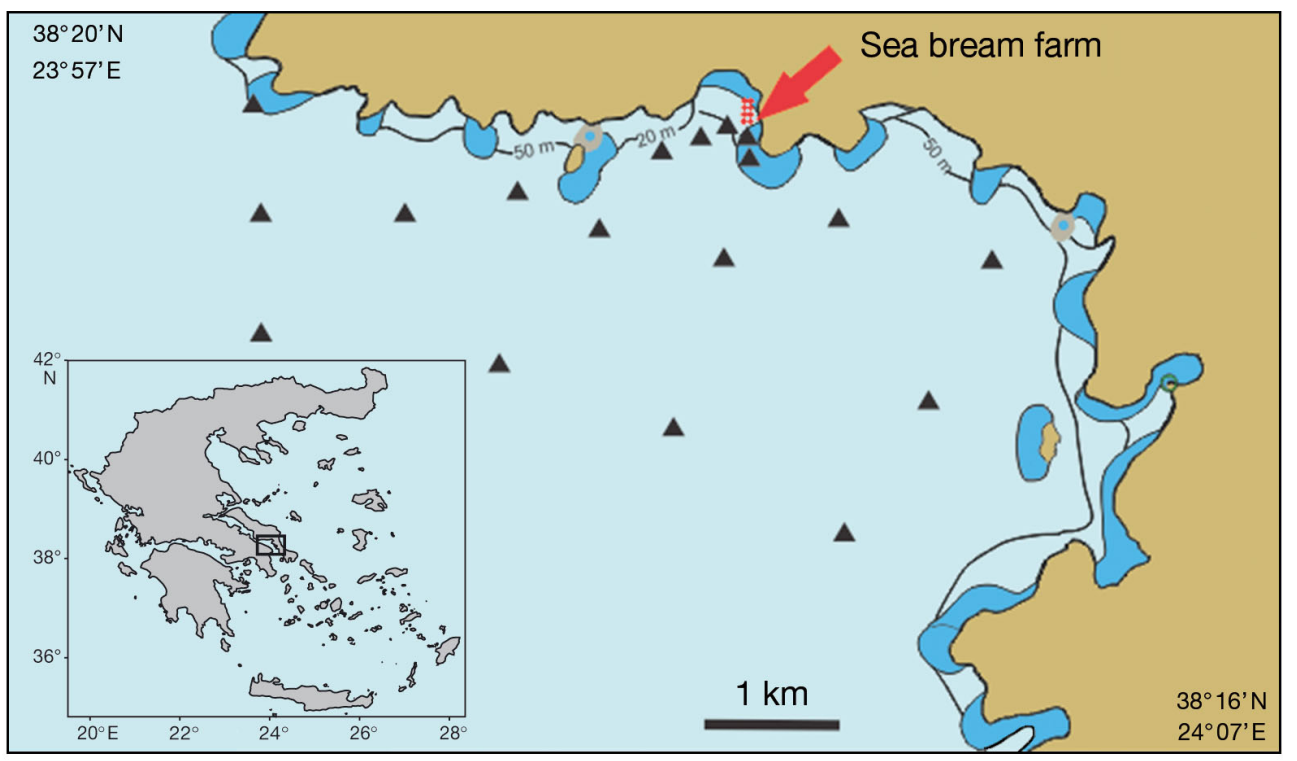

Fig. 2. Map of the ichthyoplankton survey area and location in Greece (rectangle in inset). Sampling stations (triangles) and location of the sea bream farm are also indicated (arrow) 
fish in the family Sparidae, which is a diverse family in the Mediterranean Sea. Eggs potentially belonging to the family Sparidae (Divanach 1985) were staged following a standard 11-stage system (Moser \& Ahlstrom 1985) and then put individually in $96 \%$ alcohol for molecular identification of the species (Ward et al. 2005). In stations where more than 30 sparid eggs were collected in the same stage of embryonic development, a subsample of 30-40 eggs of that stage was selected.

\section{Molecular analyses}

Eggs sampled during the ichthyoplankton surveys as well as 40 eggs collected with the experimental egg collector (see above) were individually preserved in ethanol. For the molecular analysis, total genomic DNA was extracted using the standard CTAB protocol. A region of cytochrome oxidase subunit I (COI) ( $\sim 670 \mathrm{bp}$ ) mitochondrial gene was PCR-amplified using the primers FishF2 (5'-TCAACCAACCACAAAGACATTGGCAC-3') and FishR1 (5'-TAGACTTCTGGGTGGCCAAAGAATCA-3') (Ward et al. 2005). PCRs were carried out in $10 \mu \mathrm{l}$ reactions consisting of 0.625 units of Taq polymerase, $0.15 \mu \mathrm{M}$ of each primer, $0.5 \mu \mathrm{M}$ of each dNTP, $2.5 \mathrm{mM}$ of $\mathrm{MgCl}_{2}, 1 \times$ PCR buffer, 20-50 ng of template DNA and sterile distilled water. Amplification conditions were as follows: $150 \mathrm{~s}$ at $95^{\circ} \mathrm{C}, 35$ cycles of $30 \mathrm{~s}$ at $94^{\circ} \mathrm{C}, 30 \mathrm{~s}$ at $52^{\circ} \mathrm{C}$ and $60 \mathrm{~s}$ at $72^{\circ} \mathrm{C}$ and a final elongation of $300 \mathrm{~s}$ at $72^{\circ} \mathrm{C}$. PCR products were purified by ethanol precipitation and single-stranded sequencing was performed with the primer FishF2 using the Big-Dye Terminator Cycle sequencing kit (v. 3.1, Applied Biosystems) on an ABI 3730 automated sequencer following the manufacturer's protocol. Sequence base-calling was improved using PeakTrace Online (www.nucleics. com/peaktrace-sequencing/index.php). Additional sequences for Sparus aurata and Diplodus vulgaris were used to align the sequences obtained in the present study and finally to assist molecular taxonomic egg identification. To group the various sequences obtained, a phylogenetic tree was constructed in MEGA using the Kimura 2-parameters model and 10000 bootstraps with pairwise deletion of sites in case of different lengths among sequences.

\section{Ageing of eggs}

The mean temperature in the upper water column (0-10 m) during the ichthyoplankton survey (January
Table 2. Sparus aurata. Calculations of temperaturedependent duration from fertilization to end of specific egg stages; combined information from Polo et al. (1991), Divanach (1985) and Koumoundouros (1993). The average temperature in the survey area was $15.65^{\circ} \mathrm{C}$. Stage II begins with the division of the single cell into two cells and ends at the appearance of the segmentation cavity; Stage IV: ends with the germ ring enveloping two-thirds of the yolk; Stage IX ends with the tail extending onehalf the yolk sac length; Stage $\mathrm{X}$ ends when the tail reaches three-quarters of the yolk sac length; and Stage XI ends at hatching

\begin{tabular}{|lc|}
\hline End of stage & Age in hours at $15.65^{\circ} \mathrm{C}$ \\
\hline II & 11.53 \\
IV & 24.63 \\
IX & 31.04 \\
X & 58.87 \\
XI (hatching) & $71.19(2.96 \mathrm{~d})$ \\
\hline
\end{tabular}

2011) was $15.7^{\circ} \mathrm{C}$. According to the egg incubation equation in Polo et al. (1991), the duration of the egg stage is $2.96 \mathrm{~d}$ at this temperature (Table 2). Furthermore, based on available information on age from fertilization to the end of specific stages of embryonic development given in Divanach (1985) and Koumoundouros (1993), we calculated that an egg would be $1 \mathrm{~d}$ old at the end of Stage IV and would become $2 \mathrm{~d}$ old when at Stage X (Table 2). Since only one egg in Stage IV and no eggs in Stage IX were found in our collections (see 'Results'), the assignment of egg stages as to the date of spawning was straightforward: age-0 eggs ( $<1$ d old) encompassed egg Stages I to IV, age-1 eggs (1-2 d old) encompassed Stages V to VIII, and age-2 eggs ( $>2$ d old) encompassed Stages X and XI.

\section{Evaluation of daily survival}

The weighted mean abundance of age-0, age- 1 and age-2 eggs was estimated for each sampling day. Station weighting factors were used that were proportional to the representative area of the station. Representative areas were determined by the polygons described by the perpendicular bisectors of lines from the station in question to adjacent stations (Somarakis et al. 2002). The difference in weighted mean abundance of age-1 eggs on sampling day 2 from age-0 eggs on sampling day 1 (age-1/age-0) was used as an estimate of daily survival of the eggs. 


\section{RESULTS}

\section{Analysis of gonads}

Monthly sea temperatures in the 5 farms (Fig. 3) showed that Farm 1 was characterized by lower temperatures, which affected the period of maturation as evidenced by the monthly changes of the gonadosomatic index (GSI). Temperatures below $13^{\circ} \mathrm{C}$ in January coincided with earlier onset of gonadal regression and the cessation of spawning (see also

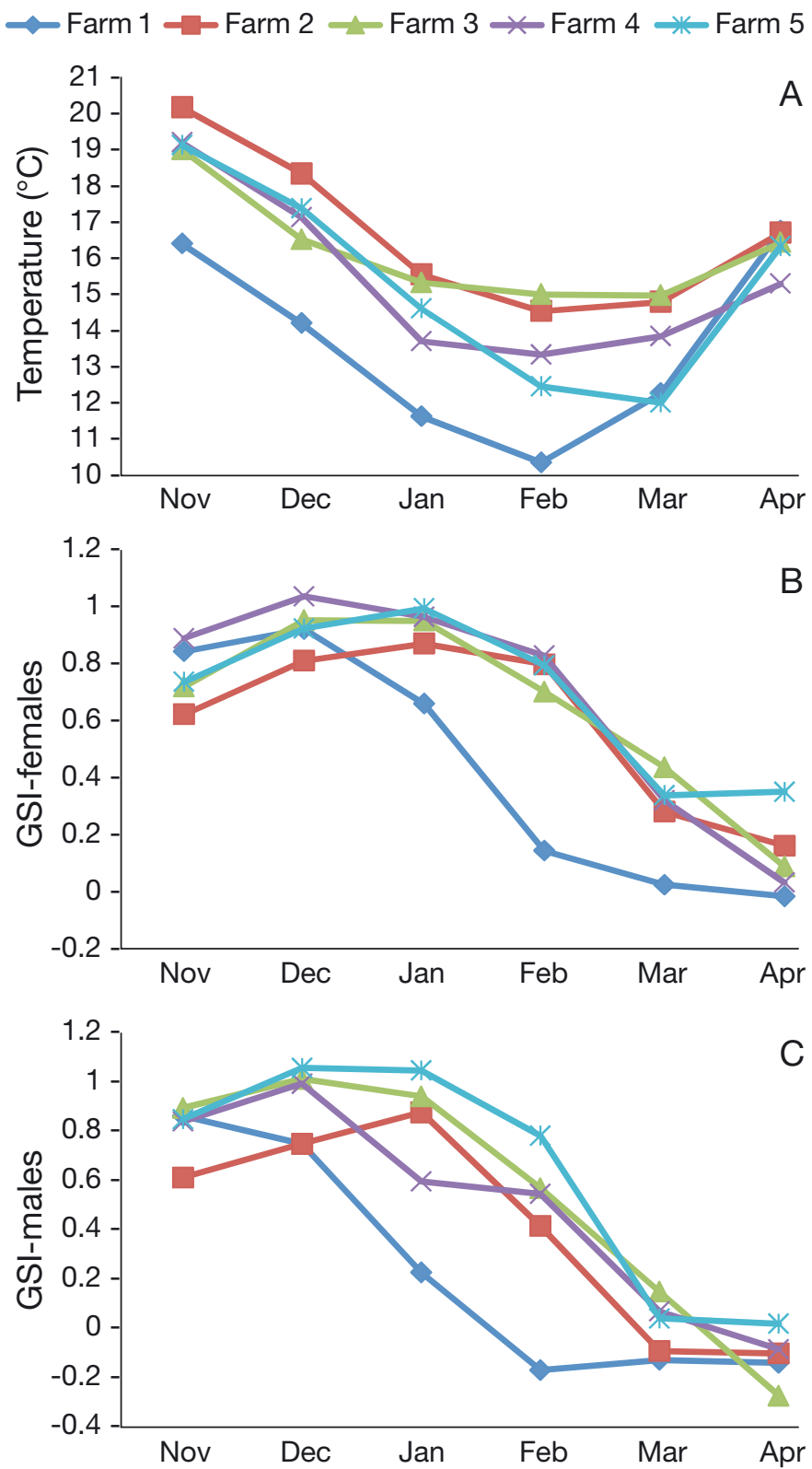

Fig. 3. Monthly changes in (A) mean water temperature and sea bream (B) female and (C) male gonadosomatic index (GSI; log-transformed) in the 5 farms
'Histological observations' below) in Farm 1. In all other farms, GSIs remained generally high until February, with gonadal regression thereafter rapid from February to April.

Histological analysis of gonads indicated that the sampled fish conformed to the general patterns of hermaphroditism already described for gilthead sea bream (Mylonas et al. 2011), although the size of the fish was generally larger than that considered in previous studies. Ovotestis of males consisted of both male (functional) and female tissue, the latter being in the primary growth phase.

There was a strong linear relationship between sex ratio (Table 1) and average mass of fish for Farms 2 to $5($ sex ratio $=0.087+0.370[$ total mass $], \mathrm{n}=4, \mathrm{p}<0.05$, $\mathrm{r}^{2}=0.987$ ), but Farm 1 had exceptionally high numbers of females $(>80 \%)$.

\section{Histological observations}

Sea bream ovaries were typical of species that exhibit asynchronous oocyte development and continuous de novo vitellogenesis (Murua \& SaboridoRey 2003). Fig. 4 illustrates females with oocytes in the primary (panels A and B) and secondary growth phase (panels C-F) (sensu West 1990). In the latter, which are spawning-capable fish (Brown-Peterson et al. 2011), oocytes in all stages of development were observed (primary, yolk vesicle, partially yolked, yolked oocytes), but their most prominent characteristic was the relatively high prevalence of atresia. Alpha-stage atresia involves the resorbing of yolk and chorion, whereas later stages (beta, gamma and delta), hereafter referred to as 'late atresia', involve the resorbing of the follicular epithelium (i.e. the granulosa cell layer and the theca that surround the developing follicle; Hunter \& Macewitz 1985).

Final maturation of the batch of eggs that will be C imminently spawned starts with the movement of all lipid globules to one side of the centrally located nucleus (Fig. 5A) and their coalescence to a single oil droplet, the subsequent migration of the nucleus to the periphery of the oocyte and its dissolution, the coalescence of yolk globules and, finally, the hydration of the oocyte, which leads to a significant increase in the size of the oocyte (Fig. 5B,D). After ovulation and spawning, postovulatory follicles (POFs) appear in the ovary (Fig. 5C,E,F) and soon start to degenerate. POFs are an unambiguous marker of recent spawning and can readily be identified in the ovaries as long as their lumen is still visible (Hunter \& Macewitz 1985). 


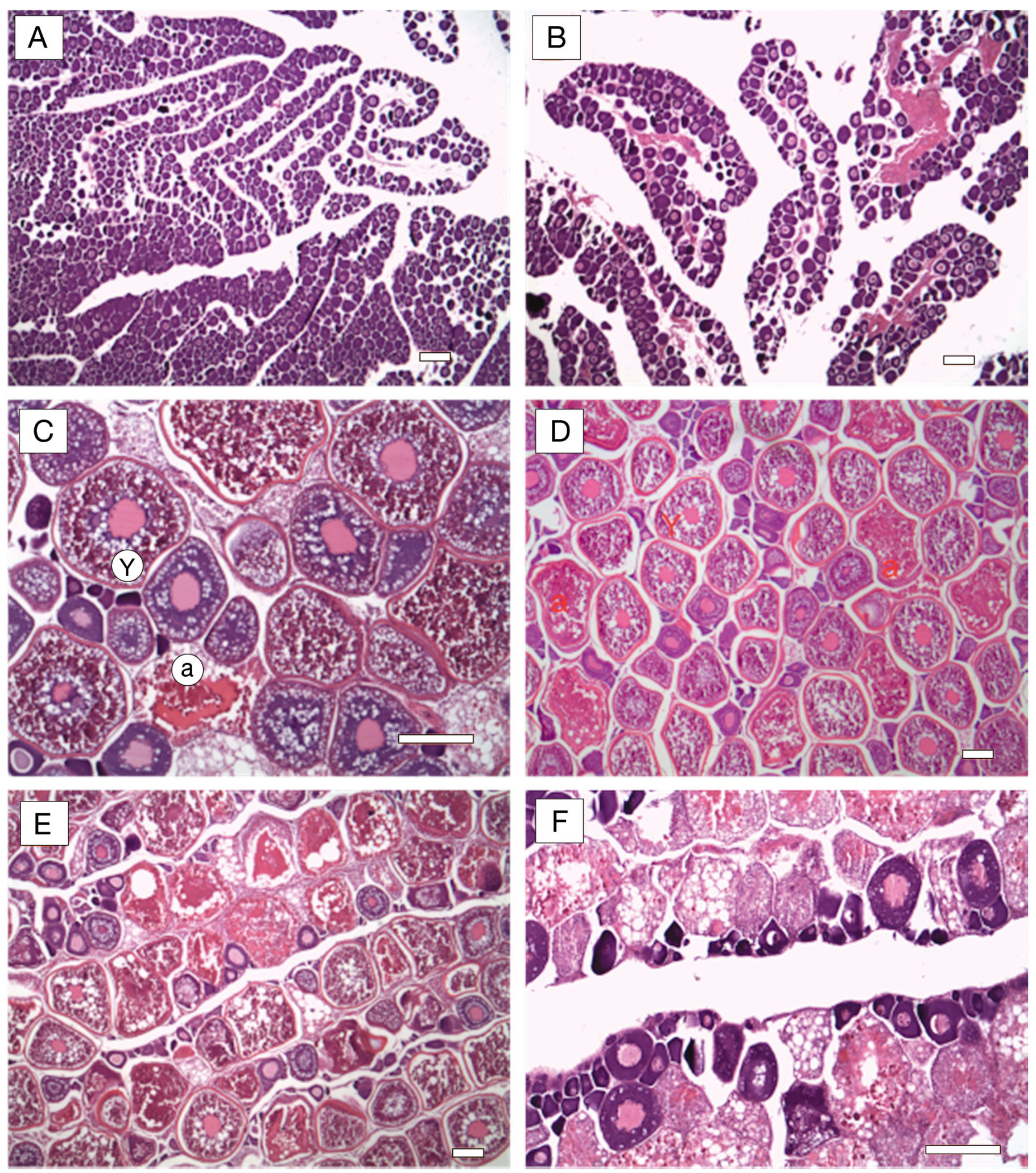

Fig. 4. Sparus aurata. Microphotographs of sea bream ovaries. (A) Virgin female in April with primary oocytes (from an ovotestis functioning as male). (B) Resting female in April with primary oocytes. (C,D) Yolked females in December with low prevalence of atresia. (E) Yolked female in December with moderate rates of atresia. (F) Female in state-2 atresia (100\% of yolked oocytes affected). Y: yolked oocyte, a: alpha-stage atretic follicle. Scale bars: $0.2 \mathrm{~mm}$ 

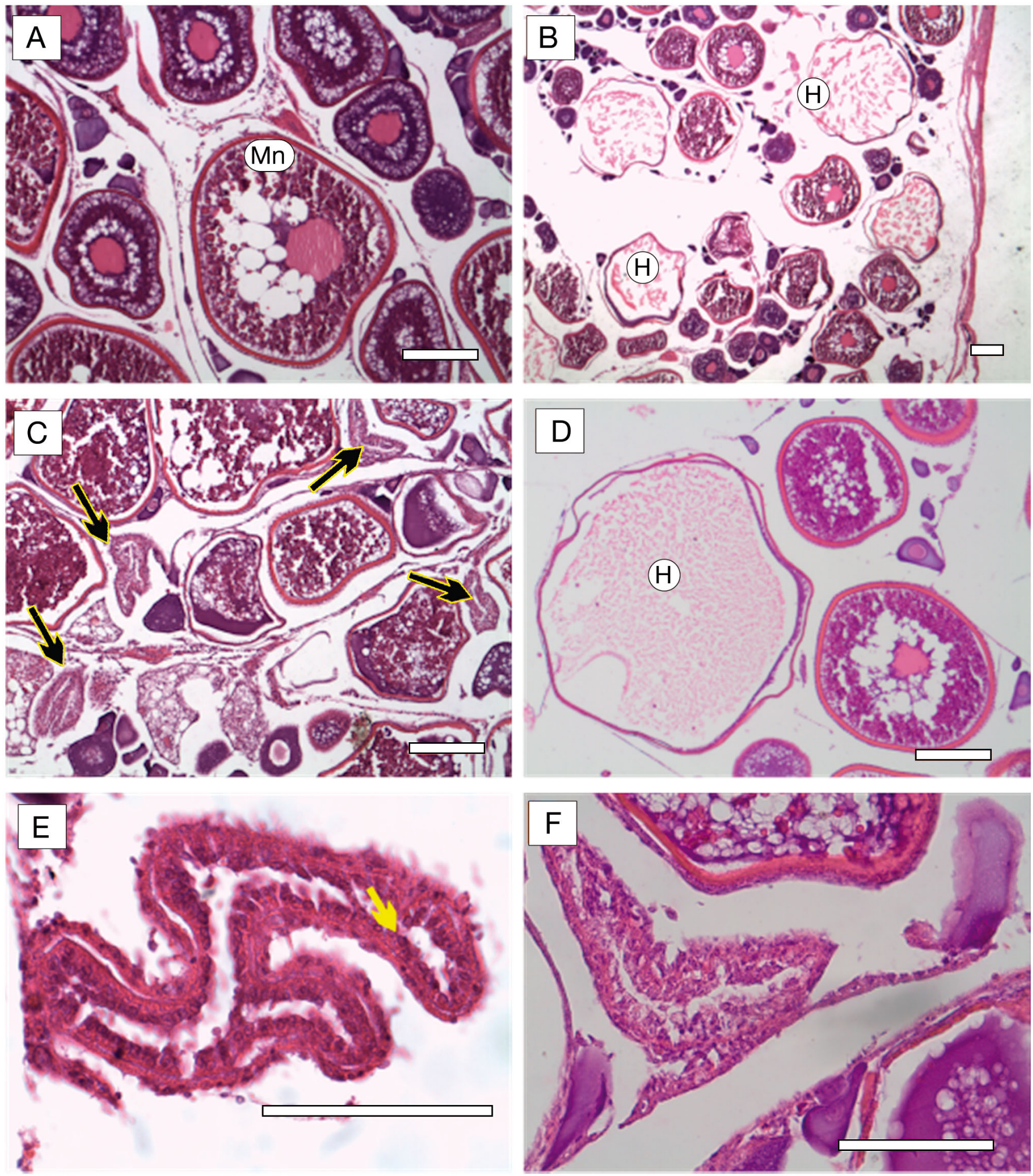

Fig. 5. Sparus aurata. Microphotographs of sea bream ovaries. (A) Oocyte at incipient final maturation (Mn). (B) Hydrated ovary. (C) Recently ovulated ovary with postovulatory follicles (POFs; black arrows). (D) Hydrated oocyte. (E,F) POFs with prominent lumen. The POF in (E) was the only one observed with few signs of degeneration. All other POFs were in moderate degeneration as shown in $(\mathrm{F})$. Yellow arrow: nuclei of granulosa cells. H: hydrated oocyte. Scale bar: 0.2 mm (A-D); 

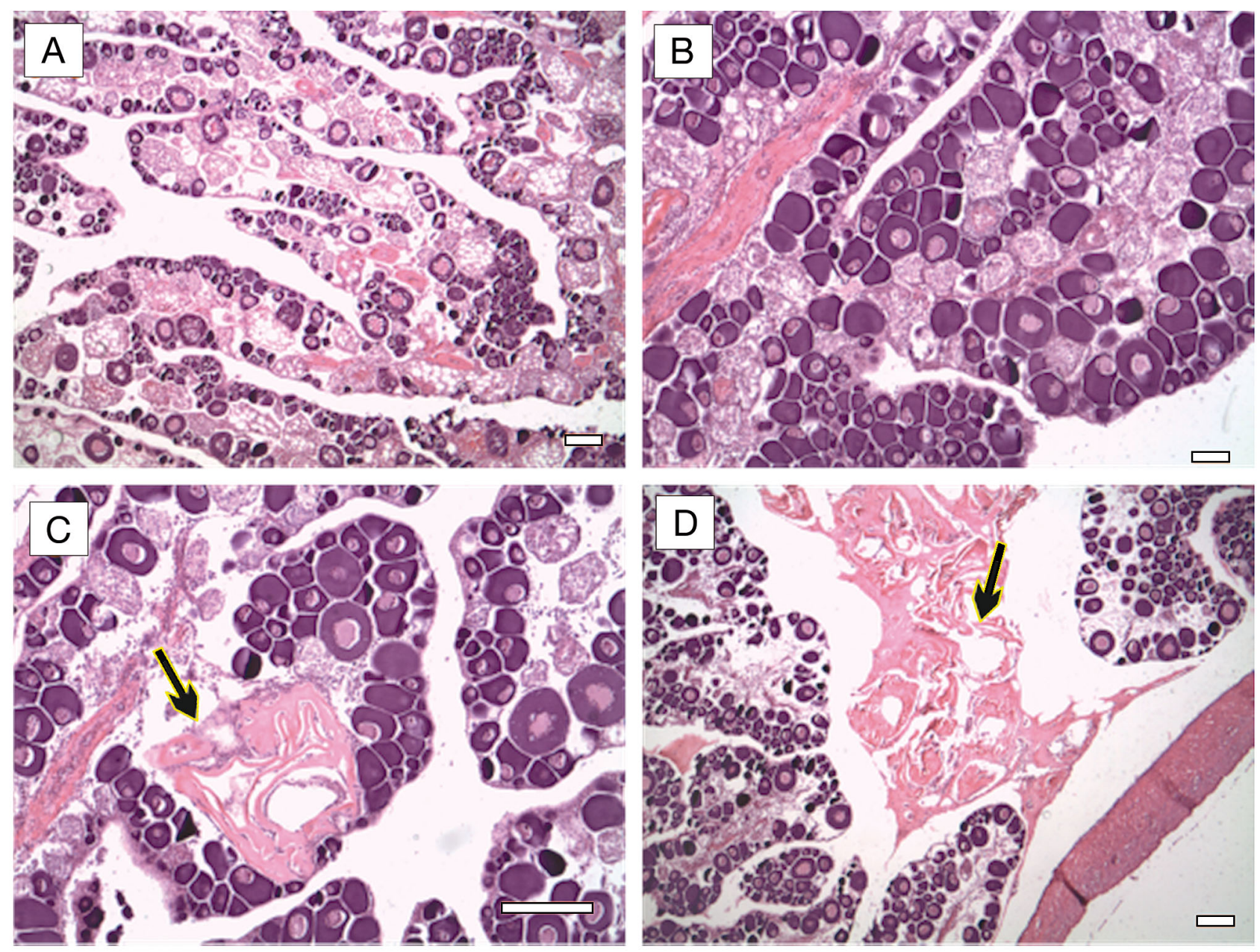

Fig. 6. Sparus aurata. (A,B) Atresia beyond the alpha stage. All yolk has been resorbed. The lower panels illustrate cysts with residual eggs (arrows) in ovaries with late atresia, either singly (C) or aggregated in the ovary lumen (D). Scale bar: $0.2 \mathrm{~mm}$

Regarding final maturation, only incipient stages of final maturation and hydrated oocytes were observed in the sea bream ovaries (samples collected in the morning), whereas oocytes in advanced nucleus migration were not recorded. This implies a daily spawning synchronicity (probably in the early night) and a time interval from initiation of final maturation to spawning of approximately $1.5 \mathrm{~d}$ (Uriarte et al. 2012).

At the end of the reproductive period, all yolked oocytes become atretic (Fig. 6) and subsequently no yolked or oocytes in alpha-stage atresia could be observed. However, late atresia was quite prominent in the early post-spawning period (Fig. 6A,B) until it became very rare, and ultimately disappeared, with ovaries containing only oocytes in the primary growth phase (Fig. 6B). Cysts with residual eggs could be observed at a high frequency in MarchApril (Fig. 6C,D).
Based on these observations, 5 histological classes were defined specifically for female sea bream (Table S1 in the supplement at www.int-res.com/ articles/suppl/q003p135_supp.pdf).

With the exception of a few males that had testes in early maturation (i.e. abundant spermatogonia, cysts with spermatocytes and spermatids but no sperm released in the lumen of lobules and ducts) (Fig. 7A), most males were mature in November-January with sperm in the lumen of lobules and ducts (Fig. 7B,C). At the end of the reproductive period, few residual sperm and some widely scattered cysts with spermatids could be observed in the testis (Fig. 7D). Subsequently, only spermatogonia and occasionally some residual sperm could be observed in the testis (Fig. 7E,F).

These observations are consistent with descriptions from Grier \& Taylor (1998) and Brown-Peterson et al. (2002) and were used to define 4 maturity classes for male sea bream (Table S1). The monthly 

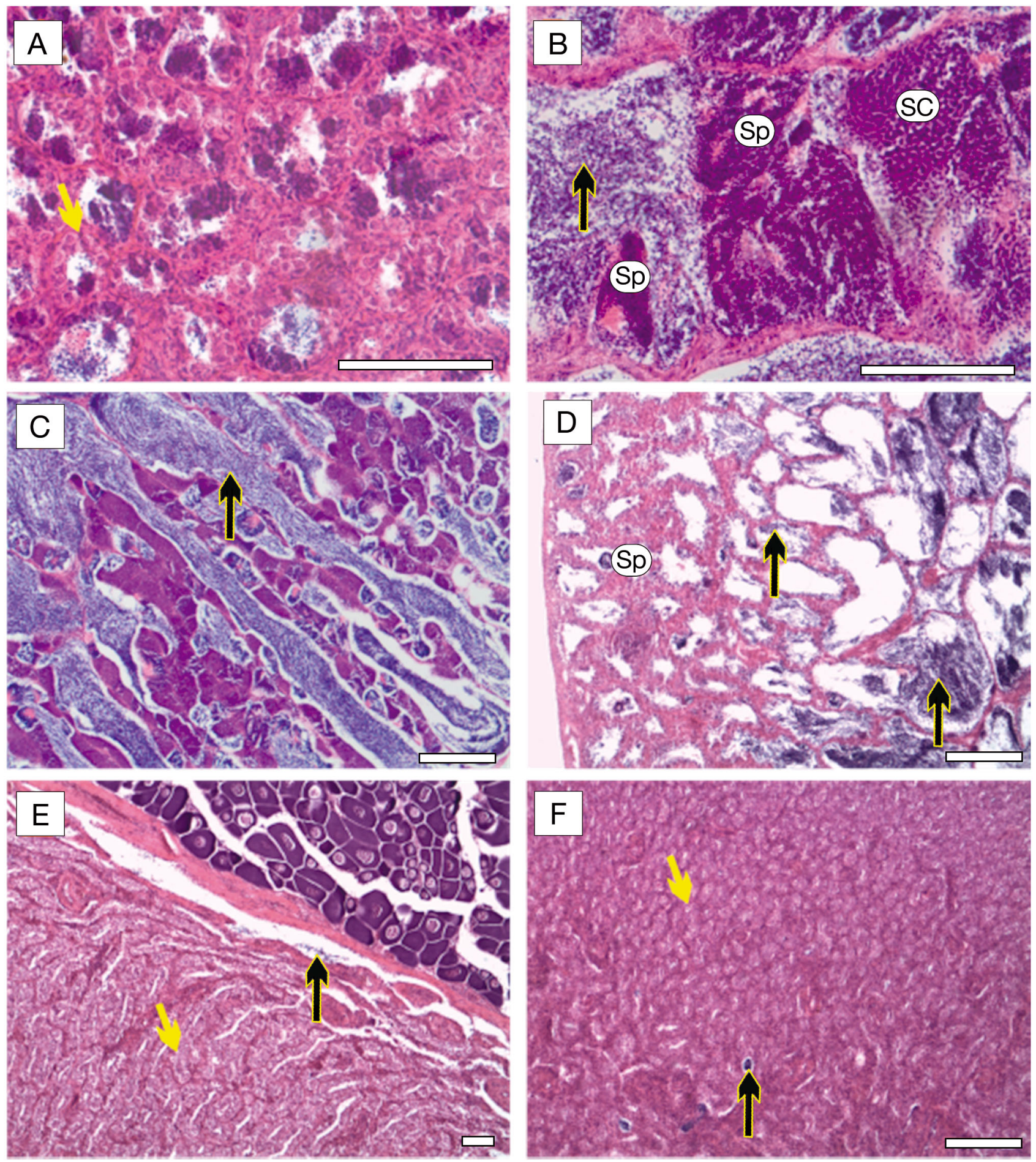

Fig. 7. Sparus aurata. Microphotographs of (A) developing, $(\mathrm{B}, \mathrm{C})$ spawning, (D) regressing and (E,F) regenerating sea bream testes. Note the ovarian tissue in (E). Yellow arrows: spermatogonia; black arrows: spermatozoa. SC: spermatocytes; Sp: spermatids. Scale bar: $0.1 \mathrm{~mm}(\mathrm{~A}, \mathrm{~B}) ; 0.2 \mathrm{~mm}(\mathrm{C}-\mathrm{F})$ 
changes in the percentages of histological classes in females and males (Table S2 in the supplement) in each of the 5 farms generally reflected the monthly changes in the GSI (Fig. 3).

\section{Spawning-capable females}

In a subsequent step of the analysis, we focused on the spawning-capable females (presence of yolked oocytes in the ovaries), for which we calculated the fraction of potentially actively spawning fish, defined as the females with signs of imminent (with oocytes in initial final maturation or hydration) or recent spawning (incidence of POFs). Such females occurred from December to March, with varying fractions among farms and months (Table 3). From December to February, most of these actively spawning fish had more than 2 spawning markers in their ovaries (Table 3), indicating a high individual inter-spawning

Table 3. Sparus aurata. Percentage of spawning-capable (with yolked oocytes) female sea bream with incidence of spawning markers or in atretic state 2

\begin{tabular}{|c|c|c|c|c|c|c|}
\hline Farm & Nov & Dec & Jan & Feb & Mar & Apr \\
\hline \multicolumn{7}{|c|}{ Actively spawning } \\
\hline 1 & & 16 & & & & \\
\hline 2 & & & 13 & 35 & 33 & \\
\hline 3 & & 32 & 61 & 21 & & \\
\hline 4 & & 22 & 44 & 70 & & \\
\hline 5 & & & 29 & 13 & & \\
\hline \multicolumn{7}{|c|}{ With 2 or 3 spawning markers } \\
\hline 1 & & 83 & & & & \\
\hline 2 & & & 67 & 50 & & \\
\hline 3 & & 33 & 13 & 100 & & \\
\hline 4 & & 100 & 86 & 86 & & \\
\hline 5 & & & 63 & 100 & & \\
\hline \multicolumn{7}{|c|}{ With hydrated oocytes } \\
\hline 1 & & 13 & & & & \\
\hline 2 & & & 8 & 9 & & \\
\hline 3 & & 21 & 39 & 14 & & \\
\hline 4 & & 11 & 13 & 60 & & \\
\hline 5 & & & 18 & 13 & & \\
\hline \multicolumn{7}{|c|}{ With postovulatory follicles } \\
\hline 1 & & 16 & & & & \\
\hline 2 & & & 13 & 9 & & \\
\hline 3 & & 16 & 8 & 14 & & \\
\hline 4 & & 22 & 31 & & & \\
\hline 5 & & & 11 & & & \\
\hline \multicolumn{7}{|c|}{ In atretic state 2} \\
\hline 1 & 0 & 10 & 100 & & & \\
\hline 2 & 0 & 10 & 4 & 43 & 67 & \\
\hline 3 & 0 & 5 & 0 & 57 & 100 & \\
\hline 4 & 0 & 11 & 6 & 30 & 100 & \\
\hline 5 & 0 & 3 & 4 & 46 & 33 & 89 \\
\hline
\end{tabular}

interval for these fish (Uriarte et al. 2012). For example, all fish with hydrated oocytes in Farm 1 in December also had both POFs and incipient final maturation oocytes in their ovaries, which implied that they were most likely spawning every day.

The fraction of females with hydrated oocytes (Table 3) can be considered as an estimate of population spawning frequency (fraction of mature females spawning each day), which, with the exception of Farm 4 in February, varied from 8 to $39 \%$ (Table 3). The high value in February for Farm 4 is probably a consequence of small sample sizes in that farm (Table 1) and was therefore considered with caution.

The fraction of females with POFs (Table 3) is another marker that is largely being used for spawning fraction estimations (Hunter \& Macewitz 1985). The POFs observed in the present study always had an evident lumen and were mostly in a moderate degree of degeneration. Given the temperature regimes in the farms and available information from POF degeneration experiments (POFs with evident lumen last for approximately $24 \mathrm{~h}$ at $13-19^{\circ} \mathrm{C}_{i}$ Alday et al. 2008 and references therein), these POFs most likely represented a single day's spawning.

Based on average fractions of hydrated females and females with POFs, we estimated that the mean of the fraction of mature females spawning each night ranged from 9.6 to $18.6 \%$ (Table 4).

Finally, we observed no actively spawning females with $>50 \%$ prevalence of atresia, implying that state-1 females (with $<50 \%$ alpha atresia) were reproductively active and state- 2 females (>50\% alpha atresia) were post-spawning. This was in agreement with Hunter \& Macewitz (1985), who defined these states in northern anchovy. Changes in the fractions of state-2 females were indicative of the termination

Table 4. Sparus aurata. Estimates of mean spawning fraction (from Table 3) and mean relative batch fecundity (from Fig. 8) DFSF: daily female-specific fecundity (number of eggs produced daily per $\mathrm{kg}$ of females in the cage, DFSF = spawning fraction $\times$ relative fecundity). Duration of the spawning period is approximated by the number of months with incidence of hydrated females and/or postovulatory follicles (from Table 3). AFSF: annual female-specific fecundity (number of eggs produced annually per $\mathrm{kg}$ of females in the cage, AFSF $=$ DFSF $\times$ spawning period)

\begin{tabular}{rrrrrrr}
\multirow{2}{*}{ Farm } & $\begin{array}{c}\text { Sex } \\
\text { ratio }\end{array}$ & $\begin{array}{c}\text { Spawning } \\
\text { fraction }\end{array}$ & $\begin{array}{c}\text { Relative } \\
\text { fecundity }\end{array}$ & DFSF & $\begin{array}{c}\text { Spawning } \\
\text { period (d) }\end{array}$ & AFSF \\
\hline 1 & 0.81 & 0.145 & 4000 & 579 & 30 & 17368 \\
2 & 0.61 & 0.096 & 14256 & 1362 & 60 & 81740 \\
3 & 0.38 & 0.186 & 16982 & 3158 & 90 & 284196 \\
5 & 0.72 & 0.103 & 8110 & 833 & 60 & 49963 \\
\hline
\end{tabular}


of the spawning season (Table 3) and were in agreement with changes in the GSI (Fig. 3) and percentages of female maturity classes (Table S2).

\section{Batch fecundity}

Batch fecundity was measured in all females with hydrated ovaries $(\mathrm{n}=37$ ). The formalin-preserved mass of ovaries was first converted to fresh mass using the following formula: fresh ovary mass $=0.742 \times$ formalin-preserved ovary mass ( $\left.n=26, r^{2}=0.960\right)$.

Surprisingly, batch fecundity was significantly and negatively correlated with the prevalence of atresia $(\mathrm{r}=-0.64, \mathrm{p}<0.01)$, rather than positively correlated with fish mass $(r=0.07, p>0.05)$. Results of the general linear models for batch fecundity and relative batch fecundity (Table 5) indicated that the 2-way interaction terms initially entered into the models (using a stepwise procedure) were not significant (including the month $\times$ farm term; Table 5). The final models were highly significant and explained a large amount of variation (>83\%; Table 5). Prevalence of atresia was the most significant factor, largely affecting (downregulating) the number of eggs per batch. Estimated marginal means of relative batch fecundity varied among farms (range: 4000-25 600 eggs kg ${ }^{-1}$ ) and months (range: 8400-18 200 eggs $\mathrm{kg}^{-1}$; Fig. 8). Batch fecundity was lower in Farms 1 and 5 than in the other farms, and higher in January than in December and February.

\section{Estimates of daily and annual fecundity}

Mean daily female-specific fecundity (DFSF) was $1163 \pm 581$ eggs $\mathrm{kg}^{-1}$ of females in the cage (mean \pm $\mathrm{SE}$ ) and ranged from 579 to 3158 eggs $\mathrm{kg}^{-1}$ of females among the 4 farms (Table 4). Annual female-specific fecundity (AFSF) was calculated as $108000 \pm$ 60081 eggs kg$~^{-1}$ of females in the cage, ranging from 17000 to 284000 eggs $\mathrm{kg}^{-1}$ of females among the farms (Table 4). Farm 4 was not used due to small sample sizes (see 'Spawning-capable females' above). Both daily and annual fecundity decreased exponentially with increasing sex ratio (Fig. 9).

\section{Egg collector experiment}

A small amount of fertilized eggs was collected daily (1250 to 3250 eggs $\mathrm{d}^{-1}$ ), apart from 2 consecutive days where larger numbers of eggs were collected (14 February 2011: 30375 eggs; 15 February 2011: 13250 eggs; Fig. 10). Further monitoring was performed (duration: $1 \mathrm{wk}$ ) in the middle of March, and no eggs were collected.

\section{Ichthyoplankton investigation}

The analyses of plankton samples (Table S3 in the supplement) revealed that sparid eggs and larvae were prominent members of the ichthyoplankton in the study area, especially during the first day of sam-

Table 5. Results of the general linear models for standardizing batch fecundity (number of eggs per batch) and relative batch fecundity $\left(\right.$ eggs $\mathrm{kg}^{-1}$ ) of sea bream Sparus aurata. Atresia: the percent of yolked oocytes in the alpha atretic stage

\begin{tabular}{|c|c|c|c|c|c|c|}
\hline Source & SS & df & MS & $F$ & $\mathrm{p}$ & Partial eta squared \\
\hline \multicolumn{7}{|l|}{$\log$ (batch fecundity) } \\
\hline Intercept & 149.815 & 1 & 149.815 & 4258.496 & $<0.001$ & \\
\hline Farm & 1.849 & 4 & 0.462 & 13.136 & $<0.001$ & 0.652 \\
\hline Month & 0.784 & 2 & 0.392 & 11.141 & $<0.001$ & 0.443 \\
\hline $\log ($ gonad-free mass) & 0.313 & 1 & 0.313 & 8.906 & 0.006 & 0.241 \\
\hline Atresia & 3.332 & 1 & 3.332 & 94.718 & $<0.001$ & 0.772 \\
\hline Error & 0.985 & 28 & 0.035 & & & \\
\hline Total & 653.109 & 37 & & & & \\
\hline Corrected total & 7.692 & 36 & & & & Adjusted $r^{2}: 0.835$ \\
\hline \multicolumn{7}{|c|}{$\log ($ relative batch fecundity) } \\
\hline Intercept & 157.807 & 1 & 157.807 & 4555.595 & $<0.001$ & \\
\hline Farm & 2.067 & 4 & 0.517 & 14.917 & $<0.001$ & 0.673 \\
\hline Month & 0.778 & 2 & 0.389 & 11.233 & $<0.001$ & 0.437 \\
\hline Atresia & 3.372 & 1 & 3.372 & 97.350 & $<0.001$ & 0.770 \\
\hline Error & 1.005 & 29 & 0.035 & & & \\
\hline Total & 637.058 & 37 & & & & \\
\hline Corrected total & 8.104 & 36 & & & & Adjusted r²: 0.846 \\
\hline
\end{tabular}



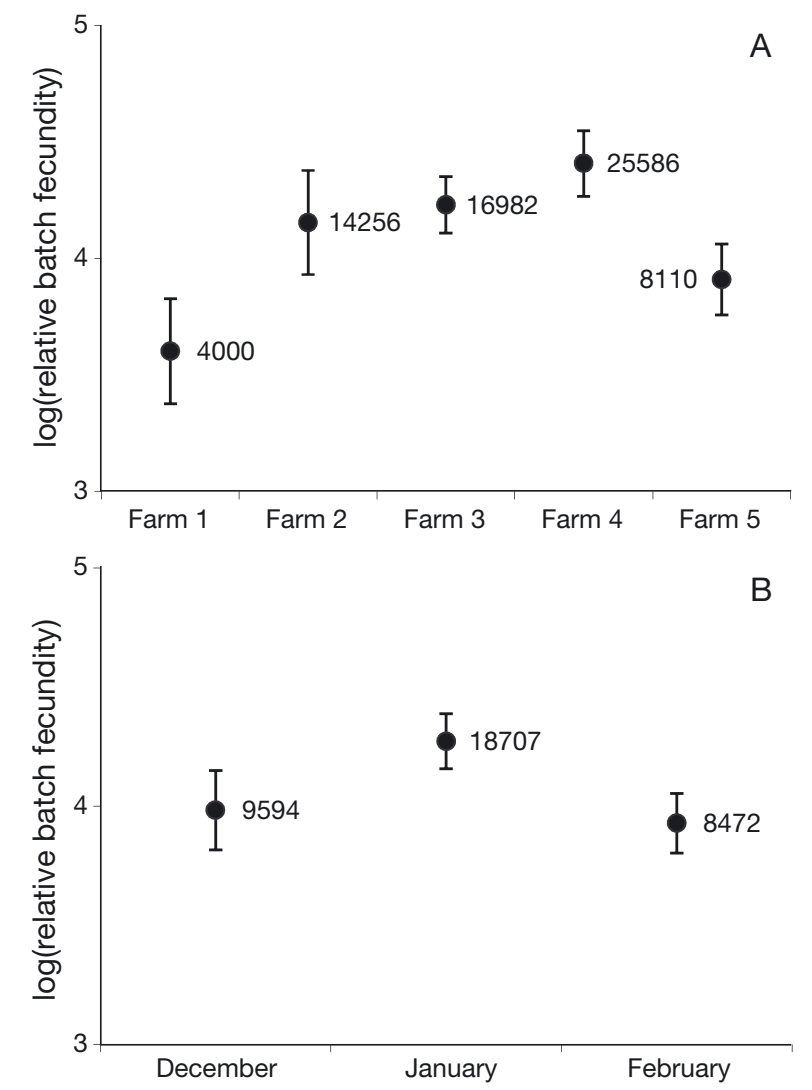

Fig. 8. Sparus aurata. Estimated marginal means with 95\% confidence intervals for relative batch fecundity (eggs $\mathrm{kg}^{-1}$ ) fixed at an atretic rate of $17.8 \%$. (A) Farms 1-5. (B) Estimates for different months. Back-transformed (anti-log) values are also indicated

pling. Larvae of epipelagic species (sardine Sardina pilchardus and horse mackerel Trachurus trachurus) and members of the Gobiidae family were also relatively abundant.

Sequences for the COI gene were successfully obtained for 247 out of the 260 individually analyzed eggs. Sequences were from 362 to 648 bp long. A total of 124 sequences were clustered with those previously reported for common two-banded sea bream Diplodus vulgaris and, therefore, they confirmed correct species allocation for these eggs. Moreover, 113 sequences were clustered with those previously reported for gilthead sea bream Sparus aurata, 6 with white sea bream Diplodus sargus and 4 with bogue Boops boops. All sequences have been deposited under GenBank accession numbers KC409395 to KC409640.

Based on the genetic identifications as well as information on station, day and stage of embryonic development, we assigned all sparid eggs to species and calculated the numbers, frequency of occurrence $(\%$ F, i.e. $\%$ of positive stations) and average abun-

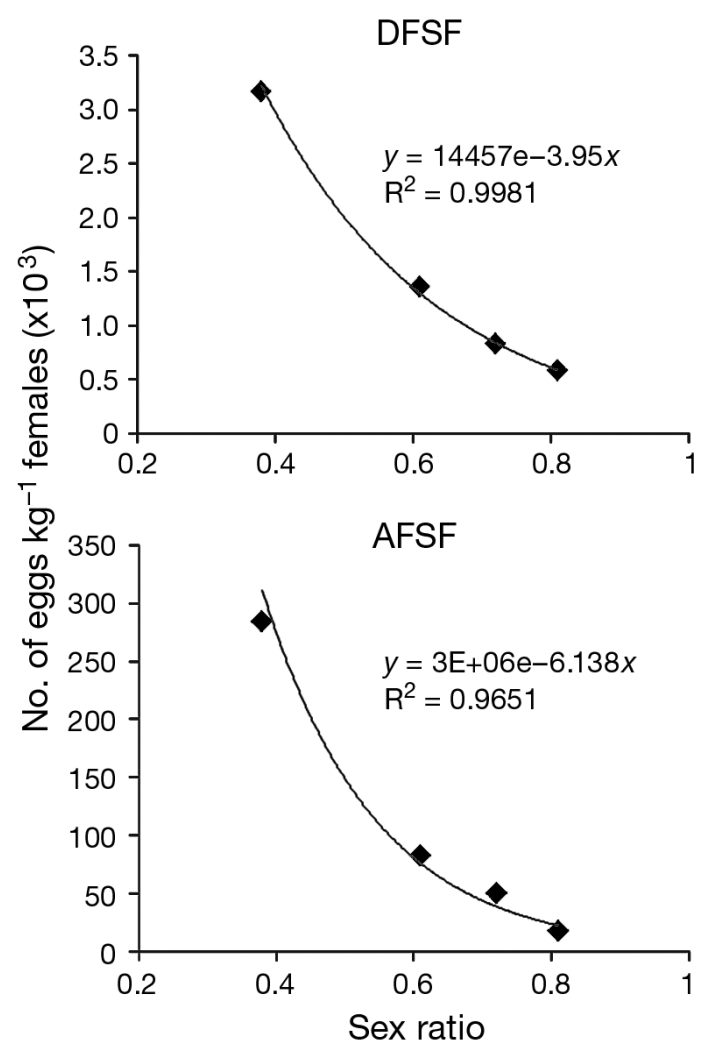

Fig. 9. Sparus aurata. Relationships between daily femalespecific fecundity (DFSF: no. of eggs produced daily $\mathrm{kg}^{-1}$ females in the cage), annual female-specific fecundity (AFSF: no. of eggs produced annually per $\mathrm{kg}$ of females in the cage) and sex ratio

dance of each species in the plankton collections (Table 6). Most sea bream eggs were collected on Day 1, whereas on Days 2 and 3 their abundance was low. Most Diplodus vulgaris eggs were also collected

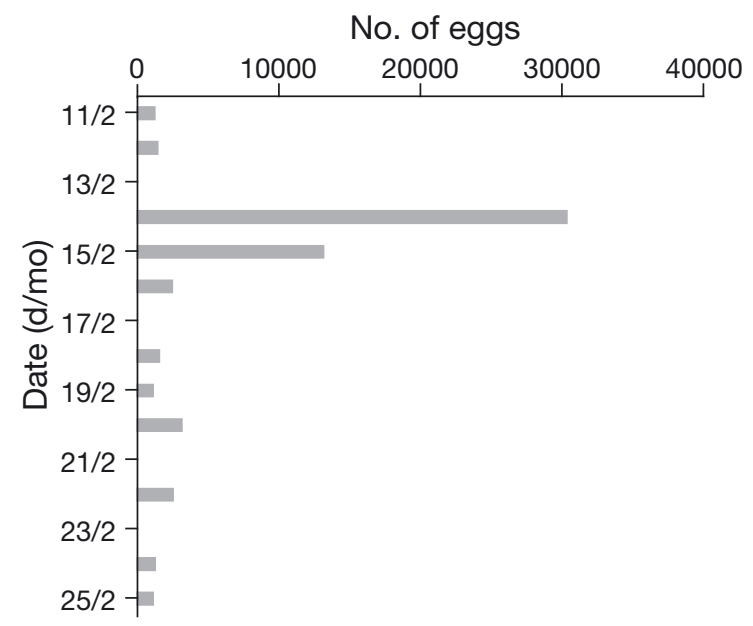

Fig. 10. Sparus aurata. Numbers of fertilized eggs collected in the sea bream cage (egg collector experiment) 
Table 6. Assignment of sparid eggs to species based on results of the genetic analyses, showing the number of individuals collected on each day $(\mathrm{N})$, the percent frequency of occurrence $(\% \mathrm{~F})$ and the average abundance at the 19 stations

\begin{tabular}{|c|c|c|c|c|c|c|c|c|c|}
\hline \multirow[t]{2}{*}{ Species } & \multicolumn{3}{|c|}{ Day $1-$} & \multicolumn{3}{|c|}{$\longrightarrow$ Day 2} & \multicolumn{3}{|c|}{ - Day $3-$} \\
\hline & $\mathrm{N}$ & $\% \mathrm{~F}$ & $\begin{array}{l}\text { Abundance } \\
\left(\text { eggs } \mathrm{m}^{-2}\right)\end{array}$ & $\mathrm{N}$ & $\% \mathrm{~F}$ & $\begin{array}{c}\text { Abundance } \\
\left(\text { eggs } \mathrm{m}^{-2}\right)\end{array}$ & $\mathrm{N}$ & $\% \mathrm{~F}$ & $\begin{array}{c}\text { Abundance } \\
\left(\text { eggs m }^{-2}\right)\end{array}$ \\
\hline Sparus aurata & 80 & 58.00 & 21.05 & 7 & 21.05 & 1.84 & 8 & 26.32 & 2.11 \\
\hline Diplodus vulgaris & 86 & 58.00 & 22.63 & 38 & 73.68 & 10.00 & 24 & 31.58 & 6.32 \\
\hline Diplodus sargus & 1 & 5.26 & 0.21 & 4 & 15.80 & 1.05 & 1 & 5.26 & 0.21 \\
\hline Boops boops & & & & & & & 4 & 21.05 & 1.05 \\
\hline
\end{tabular}

on Day 1. Furthermore, with the exception of 2 eggs that belonged to D. vulgaris, the remainder $(95 \%)$ of sparid eggs obtained in the egg collector experiment were gilthead sea bream eggs.

With regard to egg stages, most eggs of both Sparus aurata and Diplodus sargus collected were in Stages I-III (Fig. S3 in the supplement). Only one Stage-IV egg was collected late in the evening on Day 1, whereas no eggs in Stage IX were found. Eggs in late stages (X-XI) were only caught on Day 1 and they belonged to gilthead sea bream (Fig. S3).

The fraction of age-1 eggs on Day 2 to age-0 eggs on Day 1 (Table 7), expressed as a percentage, was $10 \%$ for Sparus aurata and $90 \%$ for Diplodus vulgaris. Assuming that most eggs of both species had been spawned around the cages (see below) and that no significant numbers of age- $1 D$. vulgaris eggs had been advected from outside the surveyed area, the survival of $S$. aurata eggs (most likely produced inside the cages) was very low compared with the survival of eggs from the wild population of $D$. vulgaris.

In general, the abundance of eggs of both species was higher in the stations adjacent to the farm, especially in the 2 stations that were 10 and $40 \mathrm{~m}$ away from the cages (Fig. S4 in the supplement). However,

Table 7. Sparus aurata and Diplodus vulgaris. Weighted mean abundance (eggs $\mathrm{m}^{-2}$ ) of sparid eggs per age class and sampling day. na: not applicable, no eggs were caught in this class. Note the difference between age-0 eggs on Day 1 and age- 1 eggs on Day 2 (in bold)

\begin{tabular}{|lccc|}
\hline \multirow{2}{*}{1} & Age class & S. aurata & D. vulgaris \\
\hline \multirow{4}{*}{2} & Age-0 & $\mathbf{3 . 2 2}$ & $\mathbf{6 . 9 2}$ \\
& Age-1 & 1.86 & 2.99 \\
& Age-2 & 1.94 & na \\
& Age-0 & 0.17 & 1.33 \\
3 & Age-1 & $\mathbf{0 . 3 1}$ & $\mathbf{6 . 2 1}$ \\
& Age-2 & na & na \\
& Age-0 & 0.99 & 0.39 \\
& Age-1 & na & 1.70 \\
& Age-2 & na & na \\
\hline
\end{tabular}

the picture was not very clear due to the observed high day-to-day variability in egg production. To better demonstrate the relationship of decreasing egg abundance with increasing distance from the farm, the abundance of eggs each day was standardized by dividing the individual station abundances with the maximum abundance recorded during that day. Subsequently, for each station, we averaged the abundance of eggs over the 3 days of sampling. The resulting mean standardized egg abundance against distance clearly showed that the abundance of age-0 eggs for both Sparus aurata and Diplodus vulgaris was high in the close vicinity of the farm, whereas age-1 eggs were more abundant away from the cages (Fig. 11).

\section{DISCUSSION}

\section{Spawning in sea-cages, egg dispersal and survival}

Our analysis of sea bream gonads provides the first data that female sea bream mature, ovulate and spawn within sea-cages during the normal spawning period of wild sea bream (December-March). Fecundity estimates (Table 4) indicated that actual egg production is approximately 20 times lower than those typically achieved by commercial broodstock (annual fecundity: $>2.0 \times 10^{6}$ eggs $\mathrm{kg}^{-1}$; Zohar et al. 1995, Barbaro et al. 1997, EFSA 2008, Mylonas et al. 2011, M. Pavlidis unpubl. data). Egg production may be downregulated by atresia and decreases significantly with sex ratio (i.e. with fish size in the cage). Gilthead sea bream have a complex reproductive biology and conditions within the cages are likely to be suboptimal for spawning, probably because of unbalanced sex ratios and increased stress due to overcrowding, which is likely to impede the normal performance of spawning behavior (Mylonas et al. 2011).

Genetic analysis showed that the fertilized eggs caught inside the experimental cage, using the specially manufactured egg collector, were $95 \%$ Sparus 


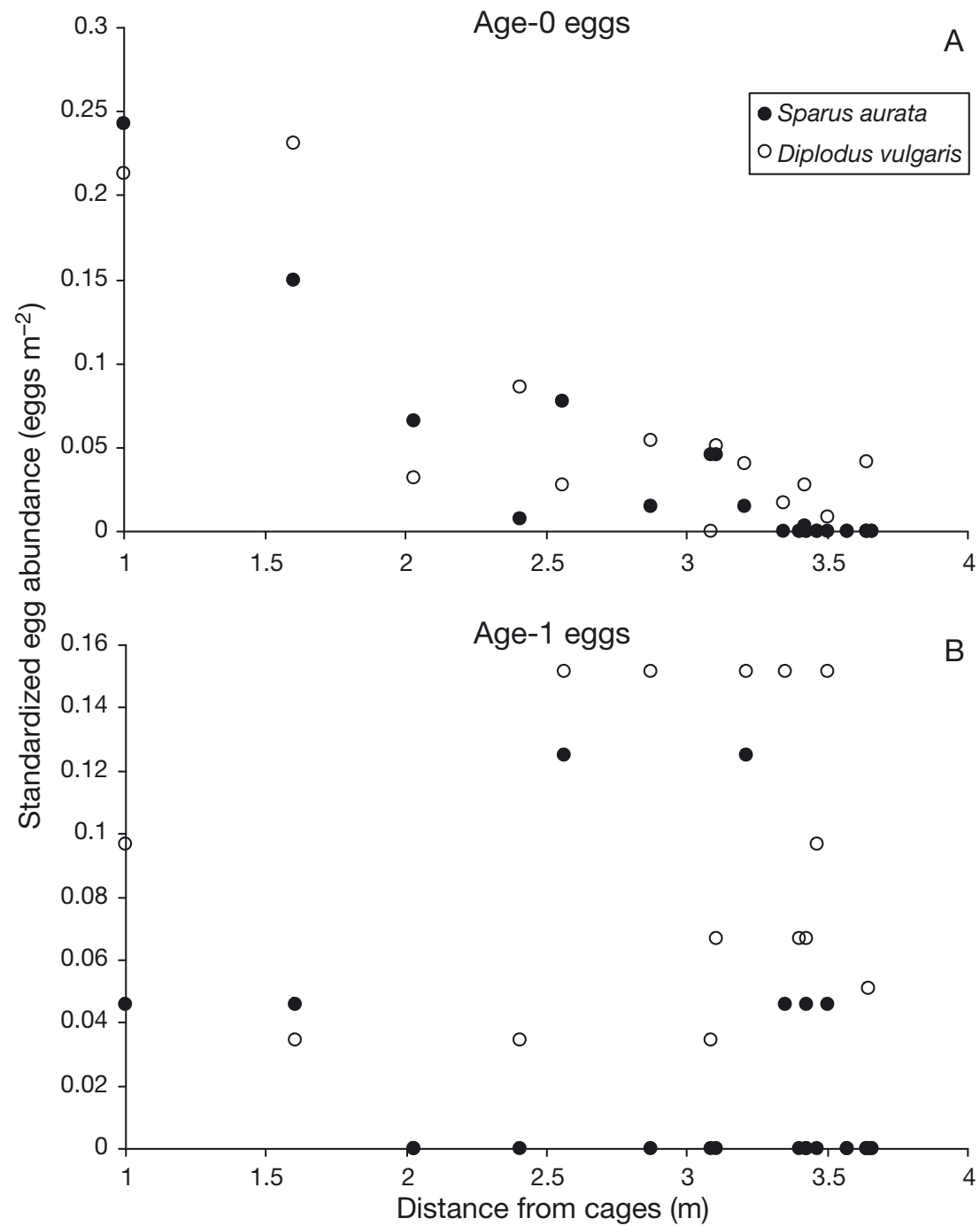

Fig. 11. Sparus aurata and Diplodus vulgaris. Plots of mean standardized egg abundance ( $\log _{10}$-transformed) against distance from the cages $\left(\log _{10}\right.$-transformed) for age-0 (A) and age-1 eggs (B) the ichthyoplankton survey was carried out (S. Kavadas, HCMR, Institute of Marine Biological Resources, pers. comm.).

Day-to-day variability in egg production by sea bream during the ichthyoplankton survey was high, which is in agreement with the findings from the egg collector experiment. Similar daily variability in egg production was observed for the wild population of Diplodus vulgaris. Further, Sparus aurata and D. vulgaris eggs showed similar patterns of distribution and dispersal around the sea-cages, with most age-0 eggs being recorded next to the cages. These findings suggest that the fish farm was a site of increased egg production of both (farmed) gilthead sea bream and other wild populations of sea bream of the same family that were attracted to the cages. The eggs are subsequently dispersed in the adjacent coastal habitat by the prevailing currents in the area, with age-1 eggs being more abundant at a moderate distance from the farm.

The daily survival estimated for Sparus aurata eggs was low (10\%) compared with Diplodus vulgaris (90\%). Although there is a high degree of uncertainty in field estimates of egg mortality (Bunn et al. 2000), the large difference in the mortality estimates for the $S$. aurata and $D$. vulgaris implies that the eggs originating from farmed gilthead sea bream may be of inferior quality. Further research is needed on the quality of eggs produced by farmed gilthead sea bream within commercial sea-cages to confirm whether aurata, which confirmed the findings of the reproductive study. Eggs are produced and fertilized within the sea-cages. Therefore, the S. aurata eggs caught in the ichthyoplankton survey were most likely spawned by the farmed fish inside the cages. While we cannot rule out the possibility that the $S$. aurata eggs were produced by wild fish or escapees, this is unlikely as: (1) wild gilthead sea bream do not typically associate with sea-cages in fish farms (Dempster et al. 2002, Fernandez-Jover et al. 2008); (2) escaped sea bream rapidly leave the vicinity of fish farms (Arechavala-Lopez et al. 2012); and (3) during the study period, there were no records of gilthead sea bream catch or bycatch by local fisheries in the South Evoikos Gulf, the wider area of where our low estimates of daily survival at one location can be generalized across the industry.

\section{Ecological implications of escape through spawning}

Approximately 130000 tons of sea bream were produced in 2010 throughout the Mediterranean Sea (FAO 2012), with farms predominantly concentrated in Greece and Turkey, although this is spread across 16 countries in total (Trujillo et al. 2012). While there are no direct production data available on the proportion of fish that are grown to large size, if we conservatively estimate that 5 to $10 \%$ of the sea bream reach a size at which they mature and spawn in sea- 
cages, our estimated average annual female-specific fecundity of 108000 eggs $\mathrm{kg}^{-1}$ equates to the production and release of $3.51 \times 10^{11}$ to $7.02 \times 10^{11}$ eggs $\mathrm{yr}^{-1}$ into the wider environment. While the estimated daily survival rates of eggs immediately after spawning at one farm were low $(10 \%)$, the sheer number of eggs released to the environment suggests the potential for recruitment of farm-spawned juveniles into wild populations. If one egg per million produced in sea-cages survives to adulthood, our estimates suggest that 351000 to 702000 fish $\mathrm{yr}^{-1}$ could recruit into wild populations. Where farming is intense, such as in Greece and Turkey (which encompass 49 and $31 \%$ of sea bream farming in the Mediterranean, respectively; Trujilo et al. 2012), this impact could be important in the context of overall wild sea bream populations. Existing correlational evidence suggests that this mechanism may be responsible for recruitment peaks in sea bream populations in certain coastal areas of Greece (Dimitriou et al. 2007). Further, direct evidence exists that Atlantic cod spawned in sea-cages survive to become young-of-the-year, grow and recruit to the spawning stock, and successfully reproduce (van der Meeren et al. 2012).

Our results imply that the escape of eggs from sea bream farms and their subsequent ecological consequences will likely depend upon several factors related to production, farm placement and the extent of selective breeding to increase desirable traits for aquaculture. These characteristics influence the amount of eggs produced, their survival or their impacts after survival. Industry decisions concerning the size of marketable sea bream will influence the proportion that reaches reproductive size within sea-cages and the likely output of fertilized eggs. Egg production will be increased when the sex ratio in the cages is balanced (close to $1: 1$ ), and the probability that larvae may recruit to wild populations may be increased when farms are placed in areas, such as areas with coastal lagoons, where sea bream can complete their life cycle (Dimitriou et al. 2007). Should escaped eggs produce mature fish capable of interbreeding with wild individuals, the genetic variability of cageheld sea bream, and the extent to which sea bream have been selectively bred to increase traits suitable for domestication (which may prove maladaptive in wild settings), will dictate the level of impacts on the genetic variability of wild populations. Selective breeding programs for sea bream are underway and evidence exists on the genetic differentiation of wild and farmed stocks (Loukovitis et al. 2012).

\section{Methods to prevent and mitigate escape through spawning of sea bream}

A range of management options are possible to reduce the extent of sea bream spawning in seacages or mitigate possible ecological or genetic effects if eggs are released to the environment. The use of a curtain-like egg collector, such as that manufactured in the present study, could prevent the dispersal of eggs away from the cages. Whether such devices could practically be implemented at a commercial scale requires further investigation; however, skirts that restrict water flow through sea-cages reduce oxygen levels, which has implications for fish welfare and production (Stien et al. 2012). Future studies that look into filtration as a method to remove spawned eggs must therefore also take into account the welfare of cultured fish. Other options to reduce the amounts of eggs include hybridization, sterilization and polyploidy. However, problems such as initially higher mortality, greater fingerling costs, poorer growth and consumer acceptance need to be solved first (Taranger et al. 2010). Finally, available information on gilthead sea bream ecology is sparse, but indicates that sea bream are probably estuarydependent species (Dimitriou et al. 2007). Thus, a precautionary mitigation measure to minimize any potentially negative environmental consequences of egg escape would be to prohibit the culture of large sea bream (of sizes beyond that of sex reversal) in areas close to known nursery grounds of the species, such as lagoons.

Acknowledgements. This study was part of the European project PREVENT ESCAPE: Assessing the causes and developing measures to prevent the escape of fish from seacage aquaculture (7th Research Framework Program, Grant agreement no. 226885). We thank the owners and production managers of the 5 sea bream farms for their cooperation and highly valued help. We also thank A. Siapatis, N. Nikolioudakis and E. Schismenou for their help in ichthyoplankton sampling and species identifications. Finally, we thank $\mathrm{K}$. Economaki for technical assistance in DNA sequencing.

\section{LITERATURE CITED}

Alday A, Uriarte A, Santos M, Martín I, Martinez de Murguia A, Motos L (2008) Degeneration of postovulatory follicles of the Bay of Biscay anchovy (Engraulis encrasicolus L.). Sci Mar 72:565-575

Arechavala-Lopez P, Uglem I, Fernandez-Jover D, BayleSempere JT, Sanchez-Jerez P (2012) Post-escape dispersion of farmed sea bream (Sparus aurata L.) and recaptures by local fisheries in the Western Mediterranean Sea. Fish Res 121-122:126-135

Arias A (1980) Crecimiento, régimen alimentario y repro- 
ducción de la dorada (Sparus aurata L.) y del robalo (Dicentrarchus labrax L.) en los esteros de Cadiz. Investig Pesq 44:59-83

Barazi-Yeroulanos L (2010) Synthesis of Mediterranean marine finfish aquaculture-a marketing and promotion strategy. Studies and Reviews. General Fisheries Commission for the Mediterranean, No 88. FAO, Rome

- Barbaro A, Francescon A, Bozzato G, Merlin A, Belvedere P, Colombo L (1997) Induction of spawning in gilthead seabream, Sparus aurata L., by a long-acting GnRH agonist and its effects on egg quality and daily timing of spawning. Aquaculture 154:349-359

> Brown-Peterson N, Grier HJ, Overstreet R (2002) Annual changes in the germinal epithelium determine reproductive classes in male cobia, Rachycentron canadum. J Fish Biol 60:178-202

Brown-Peterson NJ, Wyanski DM, Saborido-Rey F, Macewicz BJ, Lowerre-Barbieri SK (2011) A standardized terminology for describing reproductive development in fishes. Mar Coast Fish 3:52-70

Bruslé-Sicard S, Fourcault B (1997) Recognition of sexinverting protandric Sparus aurata: ultrastructural aspects. J Fish Biol 50:1094-1103

Bunn NA, Fox CJ, Webb T (2000) A literature review of studies on fish egg mortality: Implications for the estimation of spawning stock biomass by the annual egg production method. Science Series Technical Report, 11. CEFAS, Lowestoft, UK

CIESM (2007) Impact of mariculture on coastal ecosystems: executive summary. CIESM Workshop Monograph 32: 5-20. Available at www.ciesm.org/online/monographs/ lisboa07.pdf (accessed 31 March 2012)

Clark C (1981) Staining procedures. Williams \& Wilkins, Baltimore, MD

> Dempster T, Sanchez-Jerez P, Bayle-Sempere JT, GiménezCasualdero F, Valle C (2002) Attraction of wild fish to sea-cage fish farms in the south-western Mediterranean Sea: spatial and short-term variability. Mar Ecol Prog Ser 242:237-252

Dimitriou E, Katselis G, Moutopoulos DK, Akovitiotis C, Koutsikopoulos C (2007) Possible influence of reared gilthead sea bream (Sparus aurata, L.) on wild stocks in the area of the Messolonghi lagoon (Ionian Sea, Greece). Aquacult Res 38:398-408

Divanach P (1985) Contribution a la connaissance de la biologie et de l' élevage de 6 sparides Méditerranéens: Sparus aurata, Diplodus sargus, Diplodus vulgaris, Diplodus annularis, Lithognathus mormyrus, Puntazzo puntazzo (Poissons téléostéens). PhD dissertation, Université de Sciences et Techniques du Languedoc, Montpellier

EFSA (European Food Safety Authority) (2008) Scientific report of EFSA prepared by Working Group on seabass/seabream welfare on animal welfare aspects of husbandry systems for farmed European seabass and gilthead seabream. Annex I to The EFSA Journal 844:1-89

FAO (Food and Agriculture Organization of the United Nations) (2012) FishStat. Aquaculture production figures. Available at www.fishstat.org

> Fernandez-Jover D, Sanchez-Jerez P, Bayle-Sempere J, Valle C, Dempster T (2008) Seasonal patterns and diets of wild fish assemblages associated to Mediterranean coastal fish farms. ICES J Mar Sci 65:1153-1160

Fleming IA, Hindar K, Mjølnerød IB, Jonsson B, Balstad T, Lamberg A (2000) Lifetime success and interactions of farm salmon invading a native population. Proc R Soc Lond B Biol Sci 267:1517-1523

Grier HJ, Taylor RG (1998) Testicular maturation and regression in the common snook. J Fish Biol 53:521-542

Hunter JR, Macewitz B (1985) Measurement of spawning frequency in multiple spawning fishes. In: Lasker R (ed) An egg production method for estimating spawning biomass of pelagic fish: application to the northern anchovy, Engraulis mordax. NOAA Tech Rep NMFS 36:79-93

Hunter JR, Lo NCH, Leong RJH (1985) Batch fecundity in multiple spawning fishes. In: Lasker R (ed) An egg production method for estimating spawning biomass of pelagic fish: application to the northern anchovy, Engraulis mordax. NOAA Tech Rep NMFS 36:67-77

Jackson D, Drumm A, McEvoy S, Jensen $\varnothing$ and others (2012) A pan-European evaluation of the extent, causes and cost of escape events from sea-cage fish farming. In: PREVENT ESCAPE Project Compendium. Chapter 2. Commission of the European Communities, 7th Research Framework Program. Available at www.preventescape. eu

Jensen $\varnothing$, Dempster T, Thorstad EB, Uglem I, Fredheim A (2010) Escapes of fishes from Norwegian sea-cage aquaculture: causes, consequences and prevention. Aquacult Environ Interact 1:71-83

Jørstad KE, van der Meeren T, Paulsen OI, Thomsen T, Thorsen A, Svåsand $T$ (2008) Escapes of eggs from farmed cod spawning in net pens: recruitment to wild stocks. Rev Fish Sci 16:1-11

Kadmon G, Yaron Z, Gordin H (1985) Sequence of gonadal events and oestradiol levels in Sparus aurata (L.) under two photoperiod regimes. J Fish Biol 26:609-620

Koumoundouros G (1993) Biology of the development of the gilthead sea bream (Sparus aurata, Linnaeus, 1758, Percoidea, Sparidae) in intensive culture. MS dissertation, University of Crete, Heraklion

Loukovitis D, Sarropoulou E, Vogiatzi E, Tsigenopoulos CS, Kotoulas G, Magoulas A, Chatziplis D (2012) Genetic variation in farmed populations of the gilthead sea bream Sparus aurata in Greece using microsatellite DNA markers. Aquacult Res 43:239-246

Moser HG, Ahlstrom EH (1985) Staging anchovy eggs. In: Lasker R (ed) An egg production method for estimating spawning biomass of pelagic fish: application to the northern anchovy, Engraulis mordax. NOAA Tech Rep NMFS 36:37-41

Murua H, Saborido-Rey F (2003) Female reproductive strategies of marine fish species of the North Atlantic. J Northw Atl Fish Sci 33:23-31

Mylonas CC, Zohar Y, Pankhurst N, Kagawa H (2011) Reproduction and broodstock management. In: Pavlidis MA, Mylonas CC (eds) Sparidae: biology and aquaculture of gilthead sea bream and other species. Blackwell Publishing, Oxford, p 95-131

> Pavlidis M, Kokokiris L, Paspatis M, Somarakis S, Kentouri M, Divanach P (2006) Gonadal development in hybrids of Mediterranean sparids: Sparus aurata (female) $\mathrm{x}$ Pagrus pagrus (male). Aquacult Res 37:302-305

> Petridis D, Rogdakis Y (1996) The development of growth and feeding equations for sea bream, Sparus aurata L. culture. Aquacult Res 27:413-419

Polo A, Yúfera M, Pascual E (1991) Effects of temperature on egg and larval development of Sparus aurata L. Aquaculture 92:367-375

Somarakis S, Koutsikopoulos C, Machias A, Tsimenides N 
(2002) Applying the daily egg production method (DEPM) to small stocks in highly heterogeneous seas. Fish Res 55:193-204

Stien LH, Nilsson J, Hevrøy EM, Oppedal F, Kristiansen TS, Lien AM, Folkedal O (2012) Skirt around a salmon sea cage to reduce infestation of salmon lice resulted in low oxygen levels. Aquacult Eng 51:21-25

Taranger GL, Carrillo M, Schulza RW, Fontaine P and others (2010) Control of puberty in farmed fish. Gen Comp Endocrinol 165:483-515

Thorstad EB, Fleming IA, McGinnity P, Soto D, Wennevik V, Whoriskey F (2008) Incidence and impacts of escaped farmed Atlantic salmon Salmo salar in nature. NINA Spec Rep 36

Trujillo P, Piroddi C, Jacquet J (2012) Fish farms at sea: the ground truth from Google Earth. PLoS ONE 7:e30546

Uglem I, Knutsen Ø, Kjesbu OS, Hansen ØJ and others (2012) Extent and ecological importance of escape through spawning in sea-cages for Atlantic cod (Gadus morhua L.). Aquacult Environ Interact 3:33-49

Uriarte A, Alday A, Santos M, Motos L (2012) A re-evaluation of the spawning fraction estimation procedures for Bay of Biscay anchovy, a species with short interspawning intervals. Fish Res 117-118:96-111

Editorial responsibility: Dean Jerry,

Townsville, QLD, Australia van der Meeren T, Jørstad KE, Paulsen OI, Dahle G (2012) Offspring from farmed cod (Gadus morhua L.) spawning in net pens: documentation of larval survival, recruitment to spawning stock, and successful reproduction. ICES CM 2012/P:11, ICES, Copenhagen

Ward RD, Zemlak TS, Innes BH, Last PR, Hebert PDN (2005) DNA barcoding Australia's fish species. Philos Trans R Soc Lond B Biol Sci 360:1847-1857

West G (1990) Methods of assessing ovarian development in fishes: a review. Aust J Mar Freshw Res 41:199-222

Zohar Y, Abraham M, Gordin H (1978) The gonadal cycle of the captivity-reared hermaphroditic teleost Sparus aurata (L.) during the first two years of life. Ann Biol Anim Biochim Biophys 18:877-882

Zohar Y, Billard R, Weil C (1984) La reproduction de la daurade (Sparus aurata) et du bar (Dicentrarchus labrax): connaissance du cycle sexuel et controle de la gametogenese et de la ponte. In: Barnabe G, Billard R (eds) L'Aquaculture du bar et des Sparides. INRA, Paris, p 3-24

Zohar Y, Harel M, Hassin S and others (1995) Gilthead sea bream (Sparus aurata). In: Bromage NR, Roberts RJ (eds) Broodstock management and egg and larval quality. Blackwell Science, Oxford, p 94-117

Submitted: October 1, 2012; Accepted: January 14, 2013 Proofs received from author(s): February 20, 2013 